\title{
Preface
}

Southern California was discovered from the east, by westward moving migrants. Looked at from its eastern approaches the region could not be seen in proper perspective; its significance remained obscure. But when one approaches the region from across the Pacific, it begins to assume an altogether different aspect. The sense of detachment from the rest of the continent gives way to a feeling of its integral relation to the rest of the Pacific world.

Carey McWilliams, Southern California: An Island on the Land, 1946

Oupermarket owner Darioush Khaledi went to
survey damage at one of his stores in Compton, California, the day after riots had torn through the south Los Angeles area in 1992. He had resolved to close the store because of the damages and evident danger in the neighborhood. He was gloomy about the prospect as the riot was the first setback to the company that Khaledi and his brother-in-law, Paul Vazin, immigrants from Iran who didn't speak much English, had started in 1977. K. V. Mart Co., which catered to minority customers from Latin America and the Caribbean, had succeeded like an American dream, growing to fourteen stores and more than two hundred employees. Now, as he neared the battered store, Khaledi saw a crowd advancing across the parking lot. He looked at them in surprise. The people were carrying brooms, buckets, and sponges. They had been 
waiting to help him clean up. "We reopened that store in eight days," Khaledi recalled in $1996 .{ }^{1}$ So the dream lived on. Today, K. V. Mart has twenty-two stores in Los Angeles and Orange and Ventura counties.

Southern California is like that: unpredictable, perplexing, and vibrant. This region is at the nexus of Latin America and Asia, and in the past two decades it has opened up to economic opportunity, population growth, and enormous energy from those continents. Southern California today embodies a great shift in the United States to an economy driven by international commerce and entrepreneurial business and finance. It is an economy that receives people and investment from around the world and that is constantly renewed by changing technology. With 22 million people and a yearly output of goods and services (gross regional product) equal to or greater than that of India, Brazil, Russia, or Mexico, the half-dozen counties of Southern California lead a transformation of the U.S. economy. ${ }^{2}$

The changes of this era are comparable to those of the post-World War II period, when America moved to a national economy, distributing merchandise over interstate highways and advertising its wares on television. Los Angeles emerged into national consciousness at that time. Today, the move is to a global economy and the extraordinary communications revolution of the Internet.

I have reported on Southern California for almost forty years for Forbes magazine, the Los Angeles Times, and the New York Times. I have seen the region with a sassy sense of itself in the late 1960s, when a billboard over Olympic Boulevard advertised a radio station with the tongue-in-cheek greeting, "Smile Los Angeles, You're the Center of the Universe." I have seen it at the depth of economic depression and doubt in the early 1990s, when the aerospace-defense industry cut back and went away. And I have seen the region rise again with new industries and people. That local knowledge gives me the wherewithal to write this book. But it is my perspective gained from reporting across the globe that inspires me to write it. I have seen economic progress amid tremendous challenges in countries — such as Japan, Israel, and Ireland - that created economies based on knowledge work. I have seen hidden flaws amid seeming economic might in the Soviet Union, the Shah's Iran, Saddam's Iraq, and much else of the Middle East. And I have seen the 
struggle for human improvement that goes on in South Africa, Mexico, and China and in towns and regions across the United States.

I believe that all places of great change combine seeming chaos and positive development if energetic people are given education and freedom to improve their lives. Today, Southern California is just that kind of place, confronting challenges of poverty amid wealth, poor education and young people at risk, industrial growth, and environmental damage. The area in a sense has always been like that-and always for this region has not been a long, long time. Rather, Southern California is a new place, populated mainly during the past century and built in a hurry by energetic businesspeople and boosters who saw their opportunities in the area's climate and fertility — and took them! That boosterish strain begat in turn a critical reaction, first among writers like Upton Sinclair, James M. Cain, and Raymond Chandler, who spotted evil under the palm fronds and created a noir tradition in books and brooding movies such as Double Indemnity and Farewell, My Lovely.

The noir tradition carried over to scholarly commentary in recent decades after the growth and promise of the 1950s and 1960s turned complex and blotchy in later decades. Author Mike Davis, prominently, wrote of disintegrating social fabric and declining economic vitality in his books City of Quartz: Excavating the Future of Los Angeles (1990) and Ecology of Fear: Los Angeles and the Imagination of Disaster (1998). He saw changes occurring at the end of the 1980 s, including cutbacks in defense spending and increases in Japanese trade and investment, as foreshadowing decline. To be sure, those were troubled times, and today's environment is no picnic. But the forebodings were not borne out. The changes that came to Southern California in the 1990s turned out far better than most people predicted.

A new economy emerged from seeds planted during the old. This is the very point of this book. I don't deny there are problems; indeed, formidable challenges confront this region. Los Angeles has spectacular problems, including 250 street gangs with twenty-six thousand members, according to the Los Angeles Police Department. The gangs have committed more than twenty-three thousand serious crimes in the past five years. Today's Southern California is no Oneida Community, no Shining City on a Hill. But it is a dynamic region emblematic 
of changes in the United States and the world. My book takes off from the downturn of the early 1990 s and follows the emergence of an entrepreneurial economy that in many ways is more democratic than plutocratic. The Southern California economy of this decade-even amid present worries about a global recession-has greater variety of work and lower unemployment than in previous times. The shift in ethnic makeup throughout the region, while not without tensions, is proceeding far better than many foresaw. In private industry and government service up and down California, immigrants and their children and grandchildren are taking their places in the mainstream of American society at a pace that mirrors and often improves upon that of earlier decades and centuries of our history.

That is my perspective, optimistic perhaps, but no more so than the reasoned optimism of other students of California, such as historian Kevin Starr, Coast of Dreams (2004); author Peter Schrag, California: America's High Stakes Experiment (2006); urban historian Joel Kotkin, The City (2005); and the University of California, Irvine, scholars Rob Kling, Spencer Olin, and Mark Poster, whose Postsuburban California (1995) describes Orange County as a new landscape, one that characterizes so many urban areas of contemporary America. In short, I focus on the enterprise and achievements of the region's people, businesses, and institutions because the achievements are substantial and they're linked to historic developments in the world economy.

\section{A New Paradigm}

In this book I tell the stories of people, companies, and industries in order to illustrate the global developments affecting our economies and our lives. The first three-of eight—chapters explain the characteristics of Southern California's economy that make it a model for the United States and the world. first, there is international trade, which is now a leading contributor to the U.S. gross national product in a world economy swelled by billions of new participants - principally the enormous populations of Asia, Latin America, and Eastern Europe. In today's global trade, however, industries and countries do not merely exchange goods and services but collaborate in producing them. This is a new paradigm and a richer exchange. The ideas behind products and services are the 
most valuable factors in the process; concept and design count for more than simple manufacture. This is hardly revolutionary. The engineers who designed the automobiles have always been more highly compensated than the assembly line workers who put them together.

But we have entered a new age in which work and production are decentralized, employing many actors in a unified drama. In this new world, global businesses do not practice simple arts of export and import but the complex tasks of "supply chain management" and "framework architecture," words taken from the realm of information technology that simply mean assigning specific responsibilities to many and separate parts in a global process. The need and idea for a product may originate in one country, say, the United States, and its fabrication may occur in another, say, China, after which it is shipped back to the United States and distributed and sold there. Or a product or service may remain in China and be sold there, or China may seek to open a plant in the United States to make and sell its products here and gain a larger share of the proceeds. All these transactions are happening every day now, yet they are not broadly understood by the general public and there is frequent outcry that "China (or India) makes everything, we make nothing anymore." Chapter 1 seeks to banish such misconceptions by explaining, through examples of companies and individuals, how the world works today and why Southern California became preeminent in the nation's trade.

Significantly, Chapter 1 notes that the rapid rise of international trade in the past decade has not occurred merely because China is a large and populous country or because the Cold War ended in 1989. Trade rose to today's proportions because of the spreading use of the Internet for commerce and other purposes by individuals and organizations the world over. Southern California was present at its creation. In Chapter 2, I tell of four scientists at the University of California, Los Angeles (UCLA) who, working in collaboration with researchers at the University of California, Santa Barbara; Stanford Research Institute; and the University of Utah, "invented" the Internet on a project for the Defense Department. The Pentagon was seeking to create a totally distributed communications system, with no command centers that could be vulnerable in time of war. The ARPANET (Advanced Research Projects Agency 
Network) was created from UCLA's research and was the forerunner of today's Internet. Also, the basic scientific and technological principles that later created cellular telephony and wireless Internet communication were developed at UCLA and at the University of California, San Diego, in the 1970 s and 1980 s.

Those discoveries, which began with financial support from the Defense Department, were profound for Southern California and the broader U.S. economy. They led to the industrial environment we know to this day in which small companies can operate and innovate as well as large corporations, and often better. The Internet and inexpensive wireless communications are remaking the world as we speak, with computing and entertainment gravitating to mobile phone systems and new possibilities opening up. Chapter 2 also explains how significant it is that after initial Pentagon funding, companies and breakthroughs of the new age are financed primarily by entrepreneurial, decentralized investment rather than the federal government, as was the case during the postwar era in Southern California.

Chapter 3 explores the shift in finance to a modern economy that stresses innovation and entrepreneurial vigor. A half century ago, Southern California had many potential entrepreneurs, but it was almost impossible for them to attract financing for new businesses. Simon Ramo and Dean Wooldridge, whose names are behind two of the initials in TRW Inc., were brilliant engineers at the time, but nobody would back them on their own. Instead, prevailing industrial thinking and the Pentagon married them to a Cleveland auto parts company named Thompson because that represented better collateral. Yet the atmosphere changed profoundly during the 1980 s when venture financing, backed by family and pension trust investors, came into vogue. In Southern California, Michael Milken turned conventional wisdom on its head and sparked a spread of credit to innovative new companies. Everywhere, the corporate landscape was altered, albeit not always without pain. Chapter 3 explains crises that have recurred in Asia and in the U.S. economy because of distortions of finance and overexpansion of credit. But the chapter also explores the underlying reality of this age, in which Asia and Latin America are joining and expanding the ranks of developed industrial countries. This global expansion offers far more possibili- 
ties than pitfalls for America and the rest of the world. Chapter 3 acknowledges another shift, as Southern California has blossomed with newcomers from Korea and India, Vietnam and China, Mexico and Central America, and elsewhere. Southern California became the new Ellis Island and reaped economic energy as immigrants started businesses. "These people did not come all the way from Asia to work for a salary," observed one banker. "They came to build businesses. They were not thinking of retirement plans but of new adventures." Chapter 3 discusses several of these immigrant communities, their different approaches to business, and their contributions to the new mosaic in Southern California and the United States.

\section{Immigration and Arrival}

Chapters 4 and 5 focus on two significant groups of newcomers: the Latinos-with origins mainly in Mexico-and the Chinese. Chapter 4 explains the importance of this historic period of immigration for the U.S. economy and highlights the rising economic, social, and political role of Latino people in the American mosaic. It discusses the realities of fraught questions about illegal immigration and outlines the kinds of solutions that will be coming in the next few years as a new national administration takes office in 2009. The chapter also points out that both Latinos and recent Chinese arrivals now are less immigrant groups than emergent middle-class populations in the American mainstream. By explaining some history and profiling individuals and companies in the Latino and Chinese communities, these chapters examine businesses and individuals who are having a widening effect on the U.S. economy. Chapter 5 profiles individuals in the Chinese American community, showing how success in Southern California is creating new ventures in China. The chapter tells also of efforts to spread knowledge of Chinese culture in America and to adapt philosophies of the ancient sages Confucius and Lao-tzu to U.S. business practices.

Chapters 6 and 7 discuss new demands placed on two institutions in the Southern California economy: universities and entertainment. Both are undergoing profound change thanks to new technologies and the larger global economy. Chapter 6 focuses on universities and their role as performers of long-term research for the U.S. economy. Bell 
Laboratories once did scientific research, and the Defense Department for decades financed basic science, but such efforts now are entrusted to university departments financed by contributions from corporations and government agencies. Southern California's great phalanx of institutions, including five campuses of the University of California system, the California Institute of Technology, and the University of Southern California, are in the vanguard of pooling resources on important projects. Chapter 6 shows how every university, spurred by federal law and the hope of revenue, is stepping up efforts to transfer access to new technologies to private industry and the general public.

Chapter 7 illustrates how a founding industry of Southern California, film and television production, is now both threatened by new Internetbased technologies and offered greatly expanded horizons. Plans and strategies of Southern California companies indicate the way the world is turning both in transitions to online media and in the movement beyond exporting of films and television shows to collaborative ventures in China, India, and other countries.

Finally, Chapter 8 analyzes how Southern California proposes to meet the challenges of mobility and infrastructure, environmental accommodation, education, and social harmony for a greatly expanding and diverse population in the coming decades. The chapter explains how new models of public-private partnerships are being proposed to meet the needs for expanded infrastructure of ports, airports, roads, and water systems in times of straitened municipal and state budgets. It examines the continuing crises of subpar public schools and high dropout rates for students from poor and immigrant populations, as well as what solutions are being devised and put into practice. It looks at interracial tensions in Southern California's extraordinarily polyglot populations but does so with perspective. Today's global economy, with its pervasive effects throughout the region, opens more opportunities for young people and thereby serves to ease potential problems. Also, despite undeniable problems caused by ethnic gangs, Southern California visibly takes a certain pride in its diversity these days, proclaiming itself as a new model for America. And so it is. In assimilating new groups, as in pioneering new models for industry, Southern California provides a beacon for the entire country. 
Carey McWilliams's landmark 1949 book was called California: The Great Exception. But today, that concept is out of date. California, north and south, is the dynamic model of a Pacific-centered world. Southern California is no longer the exception, but rather the example that lights the future. 



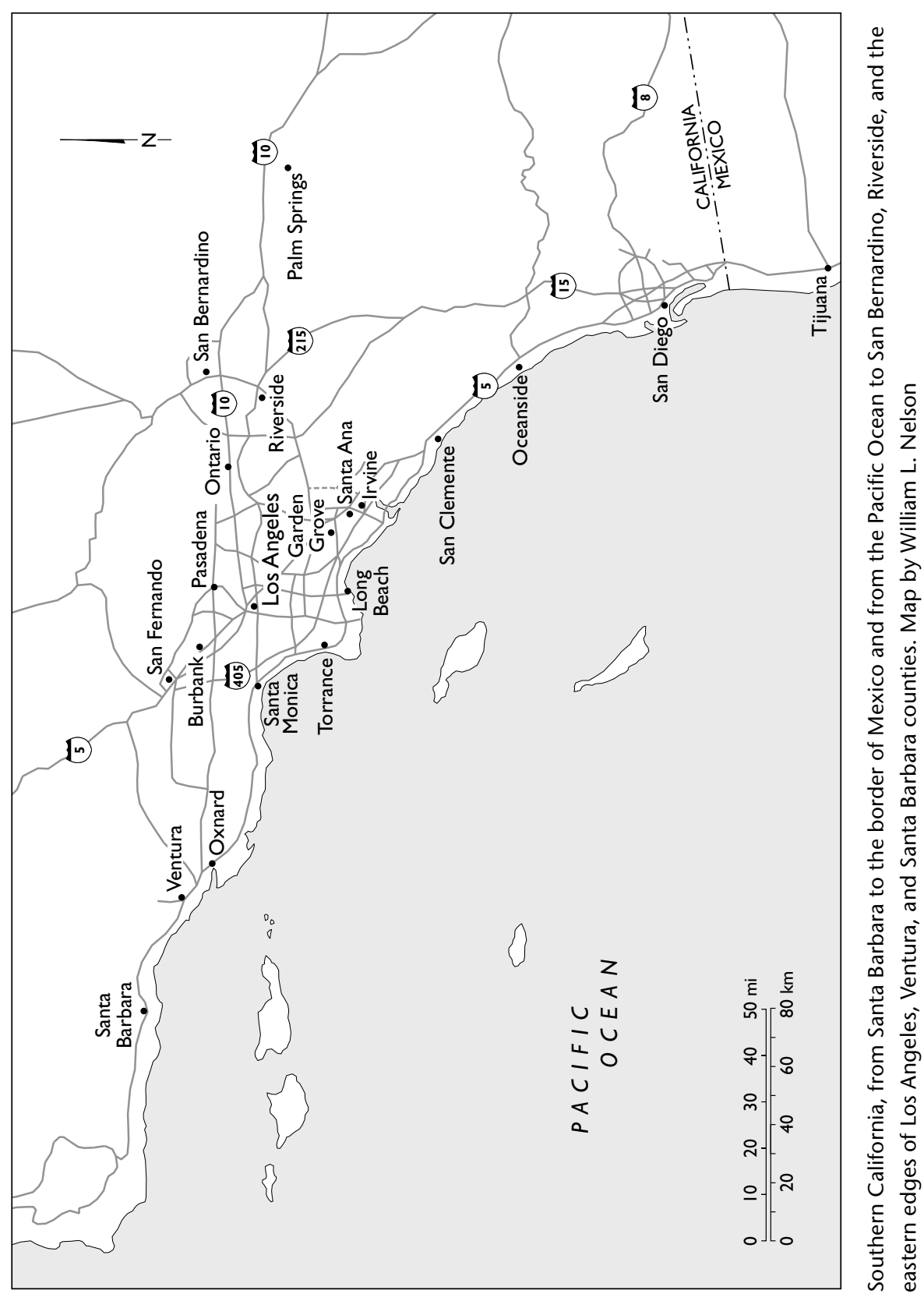


